\title{
Appropriateness of COVID-19 public health guidelines for an Alberta First Nations community
}

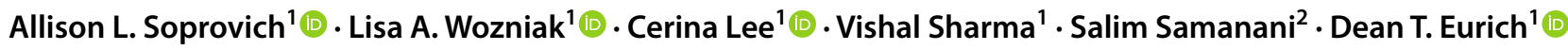

Received: 11 January 2021 / Accepted: 20 September 2021 / Published online: 3 January 2022

(c) The Author(s), under exclusive licence to The Canadian Public Health Association 2021

\begin{abstract}
Objectives The First Nations people experience significant challenges that may influence the ability to follow COVID-19 public health directives on-reserve. This study aimed to describe experiences, perceptions and circumstances of an Alberta First Nations community, related to COVID-19 public health advice. We hypothesized that many challenges ensued when following and implementing advice from public health experts.

Methods With First Nations leadership and staff, an online cross-sectional survey was deployed between April 24 and June 25, 2020. It assessed the appropriateness of public health advice to curb COVID-19 within this large First Nations community. Both quantitative and qualitative data were captured and described.

Results A total of 106 adults living on-reserve responded; over $80 \%$ were female. Difficulty accessing food was significant by employment status $(p=0.0004)$. Those people with lower income found accessing food $(p=0.0190)$ and getting essential medical care $(p=0.0060)$, clothing $(p=0.0280)$ and transportation $(p=0.0027)$ more difficult. Some respondents described lost income associated with COVID-19 experiences, as well as difficulties accessing essential supplies. Respondents found "proper handwashing" most easy (98\%) and "keeping a distance of $2 \mathrm{~m}$ from others" most difficult (23\%). Many respondents found following public health advice within their personal domain easy and put "family safety" first but experienced some difficulties when navigating social aspects and obligations, particularly when unable to control the actions of others. People stated wanting clear information, but were sometimes critical of the COVID-19 response.

Conclusion First Nations people face many additional challenges within the COVID-19 response, driven in part by ongoing issues related to significant societal, economic, and systemic factors.
\end{abstract}

\begin{abstract}
Résumé
Objectifs Les Premiers Peuples connaissent d'importantes difficultés qui peuvent nuire à la capacité de suivre les directives de santé publique sur la COVID-19 dans les réserves. Notre étude visait à décrire les expériences, les perceptions et la situation d'une Première Nation de l'Alberta en lien avec les consignes de santé publique sur la COVID-19. Nous avons postulé que de nombreuses difficultés s'ensuivent lorsque les conseils des spécialistes de la santé publique sont suivis et appliqués.

Méthode Avec les dirigeants et le personnel de la Première Nation, nous avons mené un sondage transversal en ligne entre le 24 avril et le 25 juin 2020. Le sondage évaluait la pertinence des consignes de santé publique pour contenir la COVID-19 dans cette grande communauté. Des données quantitatives et qualitatives ont été saisies et décrites.

Résultats En tout, 106 adultes vivant dans la réserve ont répondu; plus de $80 \%$ étaient des femmes. Les difficultés d'accès aux aliments selon la situation d'emploi étaient significatives $(p=0,0004)$. Les personnes à faible revenu trouvaient plus difficile d'accéder aux aliments $(p=0,0190)$ et d'obtenir des soins médicaux essentiels $(p=0,0060)$, de se procurer des vêtements $(p=0,0280)$ et de trouver de moyens de transport $(p=0,0027)$. Certains répondants ont fait état de pertes de revenus associées à leurs expériences de la COVID-19, et de difficultés d'accès aux fournitures essentielles. Les répondants ont trouvé que « bien se laver les mains » était la consigne la plus facile à respecter (98\%), et que « rester à 2 mètres les uns des autres » était la plus difficile $(23 \%)$. De nombreux répondants ont trouvé facile de respecter les consignes de santé publique dans leur domaine personnel et d'accorder la priorité à « la santé familiale », mais ont éprouvé des difficultés à négocier les obligations et aspects sociaux, particulièrement lorsqu'ils ne pouvaient pas contrôler les actions des autres. Les gens ont dit vouloir des informations claires, mais ont parfois critiqué la riposte à la COVID-19.
\end{abstract}

Extended author information available on the last page of the article 
Conclusion Les Premiers Peuples font face à de nombreuses difficultés supplémentaires dans le cadre de la riposte à la COVID-19; ces difficultés résultent en partie de problèmes persistants liés à d'importants facteurs sociétaux, économiques et systémiques.

Keywords COVID-19 $\cdot$ Coronavirus $\cdot$ Public health $\cdot$ Epidemiology $\cdot$ First Nations $\cdot$ Population health

Mots-clés COVID-19 $\cdot$ coronavirus $\cdot$ santé publique $\cdot$ épidémiologie $\cdot$ Premières Nations $\cdot$ santé des populations

\section{Introduction}

Since March 2020, the Canadian government endorsed public health guidelines to mitigate the transmission of COVID19. Likewise, the Alberta government issued directives on non-essential business closures, ceasing all non-essential travel, and restricting mass gatherings (Government of Alberta, 2020), and declared a local state of emergency in March 2020. Alberta Health Services (AHS) further released guidelines on physical distancing, cleaning protocols (including handwashing), and recommended ceasing all non-essential travel to slow the transmission of COVID-19 (Alberta Health Services, 2020).

Researchers have described COVID-19 as the "inequality virus" because it disproportionately affects marginalized groups and populations (Ali et al., 2020). One of Canada's most vulnerable populations are First Nations people living on-reserve, who are more susceptible to adverse health outcomes than the general Canadian population due to poor housing conditions (Arriagada, 2016), higher unemployment (Statistics Canada, 2015), food insecurity (Assembly of First Nations, 2011), and often geographical isolation. Past studies and reports (Kitching et al., 2020; National Collaborating Centre for Aboriginal Health, 2013) on Canada's First Nations population have predominantly shown clear disparities in burden of disease, mental health, socioeconomic status, and access to health services. In response, onreserve First Nations communities across Canada, including Alberta, instituted additional public health measures such as "sealing off" their communities from non-residents to limit the impact of COVID-19.

Despite these measures, Alberta has reported the highest number of new COVID-19 cases in First Nations communities compared to First Nations communities in other Canadian provinces and territories, with the number of overall reported cases steadily increasing since March 2020 (Government of Canada, 2020). This has further resulted in additional public health measures within the First Nations communities in response to COVID-19 outbreaks. For example, a recent outbreak of COVID-19 in one First Nations community in July 2020 resulted in curfews and hundreds of individuals/households being placed in self-isolation. Taken together, First Nations people may face increased challenges in response to COVID-19 public health advice.
With COVID-19, it is evident that there are significant societal, economic, and systemic factors that may affect the ability of First Nations people to follow public health directives. Hence, the objective of this study was to describe the experiences, perceptions and circumstances of First Nations people living in a large community in Alberta related to public health advice for COVID-19. We hypothesized that Alberta's First Nations and/or Metis peoples may experience greater challenges following and implementing advice from public health experts.

\section{Methods}

\section{Design and participants}

We actively collaborated with the leadership and staff of a large First Nations community in Alberta, Canada to develop and implement a cross-sectional survey to assess the appropriateness of public health advice to curb COVID19 within this community. The survey (see Appendix) was initiated by the health leadership within this First Nations community. In collaboration, we co-developed the survey to assist their First Nations Health Services to collect pertinent public health information around COVID-19 to make betterinformed decisions on how to support their members as the COVID-19 pandemic progresses over time, and potentially for future planning purposes.

This First Nations reserve community in rural Alberta was one of the first in Alberta to establish infrastructure and public health support systems to monitor and respond to COVID-19, including testing, case-finding, prevention, and provision of appropriate care as required, including isolation supports. Between April 24 and June 25,2020 , individuals over the age of 18 within the community were recruited to complete an online survey (one person per household) using several approaches and strategies, including invitations through social media (Twitter, community Facebook page) and other forms of public advertisements. Only one member per household was eligible to complete the survey as responses among family members would likely be similar with respect to attitudes towards public health advice around COVID-19; however, data and responses reported may only reflect the views of the individual completing the survey. 
Eligible participants who expressed interest in participating were given access to a cover letter containing relevant study information and the survey through an online portal via a unique URL. All survey information and responses were anonymous and confidentially collected in Qualtrics XM platform, which was available via cellular phones, tablets, or computers. The information collected followed OCAP (ownership, control, access, and possession) principles (First Nations Information Governance Centre, 2021) to ensure that ownership and use of the data collected will be determined by the First Nations community leadership. The study was approved by the health research ethics board at the University of Alberta (reference \# Pro00099663).

\section{Self-reported (survey) measures}

The survey aimed to specifically measure the perceived appropriateness and ability of First Nations members within the community to follow the Public Health Agency of Canada's advice to prevent and mitigate risk associated with COVID-19 within the community (https://www.canada.ca/en/public-health/services/ diseases/2019-novel-coronavirus-infection/preventionrisks.html). Specifically, questions were developed and conceptualized for the First Nations community. These included (1) basic demographics and comorbidities (e.g., age, status, employment, income, number of household members, current medical conditions); (2) public health advice or actions (e.g., confidence in the information they are receiving from various sources, ability to quarantine (self-isolate), maintain physical (social) distancing and limit contact with high-risk groups, maintain proper hand hygiene, follow travel advice); (3) impact of COVID-19 on basic living requirements (e.g., food, shelter, clothing, transportation, child care, essential medical care, safety), which are already problematic in many First Nations communities in Alberta. In addition, several open-ended questions were included to allow members to expand on their survey responses and highlight additional positive or negative experiences because of public health advice on COVID19. Where possible, questions were used or adapted from other First Nations surveys completed in the province (First Nations Information Governance Centre, 2018); however, many questions were developed specific to public health advice for COVID-19. Although all questions were piloted by researchers, health leadership, and a small number of community members, the validity or the reliability of the questions were not specifically assessed as timeliness of the information was deemed most important by the First Nations health leadership to assist in their ongoing public health response.

\section{Data management and analysis}

The data analysis was largely descriptive in nature. All variables were reported descriptively as proportions or means (standard deviations) where appropriate. In addition, differences in reported appropriateness of the public health advice or impact of COVID-19 on basic living requirements were further explored according to baseline characteristics (e.g., age, sex, comorbidities, number of household members, employment). Differences were examined using chi-square test or Student's $t$-test, as appropriate. No multivariate analyses were planned or conducted. All data analysis was conducted using the Qualtrics XM software (Qualtrics., 2005) and Microsoft Excel, or Stata MP v15 (StataCorp LLC, 2017). Responses to open-ended questions were analyzed using summative content analysis (Hsieh \& Shannon, 2005) and managed using ATLAS.ti Version 8 (Scientific Software Development $\mathrm{GmbH}$, n.d.). Responses are documented by a participant $(\mathrm{P})$ number in parentheses after direct quotes (e.g., P52).

We provided the data, preliminary analyses and all manuscript drafts to the leadership of the community for contextual interpretations and feedback. The data were returned to the leadership of the community upon completion of the study, as per OCAP (First Nations Information Governance Centre, 2021) principles.

\section{Results}

\section{Demographics}

A total of 106 people accessed and started the survey, $95(89.6 \%)$ of whom finished it. Of the total participants, over $80 \%$ were female, although no significant differences were found for other demographics based on sex (Table 1). Prior to COVID-19, $43 \%$ of participants were employed full time, $20 \%$ earned over $\$ 60,000$ annually (household income before tax), and 74\% reported living with 3 or more people. Forty-five percent of participants reported not having existing chronic conditions, $26 \%$ reported one existing chronic condition, and $21 \%$ reported two or more existing chronic conditions. All participants were living on-reserve.

\section{Meeting basic living requirements}

When asked about ability to meet basic living requirements, more than half of respondents reported some difficulty accessing clothing (58\%), essential medical care (57\%), childcare (53\%), and food (50\%) (Table 2). Accessing food was significantly related to employment status, with those "not in labour force - disabled", "unemployed" and 
Table 1 Participant characteristics

\begin{tabular}{|c|c|c|c|c|}
\hline \multirow[t]{2}{*}{ Characteristic } & \multicolumn{3}{|l|}{$n(\%)$} & \multirow[t]{2}{*}{$p$-value } \\
\hline & $\begin{array}{l}\text { Total sample } \\
(n=106)\end{array}$ & Male $(n=20)$ & Female $(n=86)$ & \\
\hline Age, years & & & & 0.3463 \\
\hline $18-30$ & $26(24.5)$ & $4(20.0)$ & $22(25.6)$ & \\
\hline $31-44$ & $32(30.2)$ & $4(20.0)$ & 28 (32.6) & \\
\hline $45-59$ & $35(33.0)$ & $10(50.0)$ & $25(29.1)$ & \\
\hline 60 or older & $13(12.3)$ & $2(10.0)$ & $11(12.8)$ & \\
\hline Missing $(n)$ & 0 & 0 & 0 & \\
\hline Marital status & & & & 0.5048 \\
\hline Never married & $38(35.8)$ & $6(30.0)$ & $32(37.2)$ & \\
\hline Married/common law & $56(52.8)$ & $13(65.0)$ & $43(50.0)$ & \\
\hline Divorced & $6(5.7)$ & $0(0.0)$ & $6(7.0)$ & \\
\hline Widowed & $6(5.7)$ & $1(5.0)$ & $5(5.8)$ & \\
\hline Missing $(n)$ & 0 & 0 & 0 & \\
\hline Education & & & & 0.1547 \\
\hline No formal education & $0(0.0)$ & $0(0.0)$ & $0(0.0)$ & \\
\hline Completed grade school (grades 1-9) & $6(5.8)$ & $3(15.8)$ & $3(3.5)$ & \\
\hline Completed high school & $36(34.6)$ & $6(31.6)$ & $30(35.3)$ & \\
\hline Completed trades certificate, college, or university & $57(54.8)$ & $10(52.6)$ & $47(55.3)$ & \\
\hline Completed graduate education (MS or $\mathrm{PhD})$ & $5(4.8)$ & $0(0.0)$ & $5(5.9)$ & \\
\hline Missing $(n)$ & 2 & 1 & 1 & \\
\hline Employment status immediately before COVID-19 & & & & 0.0830 \\
\hline Full-time & $45(43.3)$ & $9(45.0)$ & $36(42.9)$ & \\
\hline Part-time & $6(5.8)$ & $1(5.0)$ & $5(6.0)$ & \\
\hline Self-employed & $11(10.6)$ & $6(30.0)$ & $5(6.0)$ & \\
\hline Self-reliant or sufficient/living off the land & $0(0.0)$ & $0(0.0)$ & $0(0.0)$ & \\
\hline Homemaker & $8(7.7)$ & $0(0.0)$ & $8(9.5)$ & \\
\hline Not in labour force-disabled & $4(3.8)$ & $0(0.0)$ & $4(4.8)$ & \\
\hline Retired & $5(4.8)$ & $1(5.0)$ & $4(4.8)$ & \\
\hline Unemployed & $16(15.4)$ & $2(10.0)$ & $14(16.7)$ & \\
\hline Other & $9(8.7)$ & $1(5.0)$ & $8(9.5)$ & \\
\hline Missing $(n)$ & 2 & 1 & 1 & \\
\hline Annual household income & & & & 0.2838 \\
\hline$<\$ 20,999$ & $23(22.1)$ & $3(15.0)$ & $20(23.8)$ & \\
\hline$\$ 21,000-\$ 34,999$ & $23(22.1)$ & $5(25.0)$ & $18(21.4)$ & \\
\hline$\$ 35,000-\$ 59,999$ & $24(23.1)$ & $2(10.0)$ & $22(26.2)$ & \\
\hline$>\$ 60,000$ & $22(21.2)$ & $7(35.0)$ & $15(17.9)$ & \\
\hline Don’t know & $7(6.7)$ & $1(5.0)$ & $6(7.1)$ & \\
\hline Prefer not to answer & $5(4.8)$ & $2(10.0)$ & $3(3.6)$ & \\
\hline Missing $(n)$ & 2 & 0 & 2 & \\
\hline Living arrangement immediately before COVID-19 & & & & 0.6363 \\
\hline Own house or condominium & $52(50.5)$ & $12(63.2)$ & $40(47.6)$ & \\
\hline Renting, rooming house & $36(35.0)$ & $5(26.3)$ & $31(36.9)$ & \\
\hline Staying with family or friends/couch surfing & $11(10.7)$ & $1(5.3)$ & $10(11.9)$ & \\
\hline Shelter & $1(1.0)$ & $0(0.0)$ & $1(1.2)$ & \\
\hline Without a place to stay/homeless & $0(0.0)$ & $0(0.0)$ & $0(0.0)$ & \\
\hline Prefer not to answer & $3(2.9)$ & $1(5.3)$ & $2(2.4)$ & \\
\hline Missing $(n)$ & 3 & 1 & 2 & \\
\hline Number of people living in the household & & & & 0.6398 \\
\hline $1-2$ & $26(26.3)$ & $5(27.8)$ & $21(25.9)$ & \\
\hline $3-5$ & $49(49.5)$ & $9(50.0)$ & $40(49.4)$ & \\
\hline $6-8$ & $22(22.2)$ & $3(16.7)$ & $19(23.5)$ & \\
\hline 9 or more & $2(2.0)$ & $1(5.6)$ & $1(1.2)$ & \\
\hline
\end{tabular}


Table 1 (continued)

\begin{tabular}{|c|c|c|c|c|}
\hline \multirow[t]{2}{*}{ Characteristic } & \multicolumn{3}{|l|}{$n(\%)$} & \multirow[t]{2}{*}{$p$-value } \\
\hline & $\begin{array}{l}\text { Total sample } \\
(n=106)\end{array}$ & Male $(n=20)$ & Female $(n=86)$ & \\
\hline Number of existing chronic conditions & & & & 0.9739 \\
\hline 0 & $48(45.3)$ & $9(45.0)$ & 39 (45.4) & \\
\hline 1 & $28(26.4)$ & $5(25.0)$ & $23(26.7)$ & \\
\hline 2 or more & $22(20.8)$ & $4(20.0)$ & $18(20.9)$ & \\
\hline Missing $(n)$ & 8 & 2 & 6 & \\
\hline
\end{tabular}

Table 2 Struggles meeting basic living requirements, overall $(n=106)$

\begin{tabular}{lllllll}
\hline Living requirement & \multicolumn{1}{l}{$n(\%)$} & & & Missing $(n)$ \\
\cline { 2 - 6 } & Not at all & Sometimes & Often & Always & $\begin{array}{l}\text { N/A, Don't know, prefer } \\
\text { not to answer }\end{array}$ \\
\hline Food & $50(50.5)$ & $35(35.4)$ & $8(8.1)$ & $5(5.1)$ & $1(1.0)$ & 7 \\
Shelter & $83(84.7)$ & $8(8.2)$ & $3(3.1)$ & $4(4.1)$ & $0(0)$ & 8 \\
Getting essential medical care & $43(43.4)$ & $33(33.3)$ & $14(14.1)$ & $6(6.1)$ & $3(3.0)$ & 7 \\
Clothing & $42(42.4)$ & $33(33.3)$ & $15(15.2)$ & $7(7.1)$ & $2(2.0)$ & 7 \\
Transportation & $72(73.5)$ & $17(17.3)$ & $5(5.1)$ & $4(4.1)$ & $0(0)$ & $26(27.0)$ \\
Childcare & $47(49.0)$ & $13(13.5)$ & $5(5.2)$ & $5(5.2)$ & & 10 \\
\hline
\end{tabular}

"other" experiencing more difficulty $(p=0.0004)$ (Table A, Supplementary material). Transportation was significantly more difficult for those "staying with family or friends/ couch surfing" ( $p=0.0070)$. Participants earning less than \$20,999 annually experienced significantly more difficulty accessing food $(p=0.0190)$, getting essential medical care $(p=0.0060)$, and finding essential clothing $(p=0.0280)$ and transportation $(p=0.0027)$ (Table B, Supplementary material).

Related to basic needs, some respondents described lost income associated with COVID-19 experiences, including "Sales have suffered to the point that I didn't make my sales quotas" (P5) and "[I was] sent home from work for 10 days because of [a respiratory health issue] and losing out on pay" (P12). In addition, respondents reported difficulties accessing supplies during COVID-19, including personal protective equipment like hand sanitizers and masks.

"Hardest part on disability income is getting the supplies needed. And when do find stuff, it is higher priced, as no name sells out first" (P18).

"Everyone hoarded so [hand] sanitizers were hard to find as were other cleaning products. Masks are even harder to find" (P42). Some caregivers said bringing family members essential supplies was challenging, as was helping coordinate medical care. "It was a bit difficult because I was the one to get supplies, food, medication for my elderly mother" (P48).

\section{Ability to follow public health advice}

Related to ease of following public health advice, respondents found "proper handwashing" most easy (98\%) and "keeping a distance of $2 \mathrm{~m}$ from others" most difficult (23\%) overall. Ability to follow public health advice did not differ significantly by gender (Table 3 ), employment status (Table D, Supplementary material), or number in the household (Table E, Supplementary material). However, people with two or more chronic conditions reported more difficulty to "self-isolate by staying home and monitor yourself for symptoms" ( $p=0.0276)$ (Table E, Supplementary material). Additionally, people aged under 44 reported more difficulty to "keep a distance of $2 \mathrm{~m}$ from others", and those aged 45 and over did not $(p=0.0306)$ (Table E, Supplementary material). Income, living arrangements and educational level did not result in significant differences in experiences with public health guidelines (data not shown).

When allowed to expand on their survey responses related to public health advice through open-ended text, many respondents found it easier to follow public health advice within their personal domain, such as handwashing, wearing masks, limiting excursions to protect their families and 
Table 3 Experiences with public health guidelines $(n=106), n(\%)$

\begin{tabular}{|c|c|c|c|}
\hline \multirow[t]{2}{*}{ Guideline } & \multirow[t]{2}{*}{ Total } & \multicolumn{2}{|l|}{ Gender } \\
\hline & & Male & Female \\
\hline \multicolumn{4}{|l|}{ Proper handwashing } \\
\hline Easy & 98 (98.0) & 17 (94.4) & $81(98.8)$ \\
\hline Difficult & $2(2.0)$ & $1(5.6)$ & $1(1.2)$ \\
\hline \multicolumn{4}{|c|}{ Alcohol-based hand sanitizer } \\
\hline Easy & $82(82.8)$ & $15(83.3)$ & $67(82.7)$ \\
\hline Difficult & $17(17.2)$ & $3(16.7)$ & $14(17.3)$ \\
\hline \multicolumn{4}{|c|}{ Avoiding crowded places and non-essential gatherings } \\
\hline Easy & $82(82.0)$ & $13(72.2)$ & $69(84.1)$ \\
\hline Difficult & $18(18.0)$ & $5(27.8)$ & $13(15.9)$ \\
\hline \multicolumn{4}{|c|}{ Limiting contact with people at higher risk } \\
\hline Easy & $79(79.8)$ & $13(72.2)$ & $66(81.5)$ \\
\hline Difficult & $20(20.2)$ & $5(27.8)$ & $15(18.5)$ \\
\hline \multicolumn{4}{|c|}{ Keeping a distance of $2 \mathrm{~m}$ from others } \\
\hline Easy & $76(76.8)$ & $16(88.9)$ & $60(74.1)$ \\
\hline Difficult & $23(23.2)$ & $2(11.1)$ & $21(25.9)$ \\
\hline \multicolumn{4}{|c|}{ Self-isolate by staying home and monitoring for symptoms } \\
\hline Easy & $86(86.9)$ & $15(83.3)$ & $71(87.7)$ \\
\hline Difficult & $12(12.1)$ & $2(11.1)$ & $10(12.3)$ \\
\hline Prefer not to answer & $1(1.0)$ & $1(5.6)$ & $0(0.0)$ \\
\hline \multicolumn{4}{|c|}{ Self-isolate by avoiding contact with others } \\
\hline Easy & $82(84.5)$ & $14(82.4)$ & $68(85.0)$ \\
\hline Difficult & 13 (13.4) & $1(5.9)$ & $12(15.0)$ \\
\hline Prefer not to answer & $2(2.1)$ & $2(11.8)$ & $0(0.0)$ \\
\hline \multicolumn{4}{|l|}{ Follow travel advice } \\
\hline Easy & $84(85.7)$ & $16(94.1)$ & $68(84.0)$ \\
\hline Difficult & $14(14.3)$ & $1(5.9)$ & $3(16.0)$ \\
\hline Missing $(n)$ & 11 & 4 & 7 \\
\hline
\end{tabular}

putting "family safety" first. In this way, respondents had the choice to adapt their individual behaviour and follow recommended guidelines to protect the family unit, including income security: "I refuse to put my family and myself at risk so I make sure to abide by the rules" (P47). Others with challenging or toxic family relationships found benefit in following public health guidelines: "I don't need to make excuses to not go to family gatherings. I have disassociated with toxic family members over the last couple of years. This helps" (P5).

Several respondents also described needing to visit public spaces, such as medical centres or grocery stores, making it more difficult to maintain physical distance and stay home: "Not easy to stay home when I have to go to the city for appointments and medical supplies" (P24). Others living with existing medical conditions found it hard to stay home when "[I'm] still having to venture out for supplies" (P31) and medical care. In contrast, other respondents said they did not have to change at all because their behaviours prior to COVID-19 were already in line with public health advice, such as "already self-isolating before the pandemic". Another respondent explained, "Most [guidelines] was part of my everyday life" (P10).

In some cases, people's work situations made it harder or easier to follow public health advice. Some respondents described challenges following public health advice because their job required them to "travel to get supplies almost everyday" (P50). However, this person also said, "practicing safe measures is a must now" to maintain his/her job (P50). In contrast, other people reported less difficulty to follow public health advice when they could maintain and adapt their jobs/careers by working from home:

“It was easier for my family... my family didn't have to work outside the home [and] our jobs we could accomplish online" (P86).

Some respondents reported their employers were taking precautions while others did not:

"I work at a grocery store and they have made the necessary precautions for us to feel safe at work by providing us with the tools and sanitizers we need" (P81). "My husband's work did not provide extra safety measures and only enacted work hour cutbacks to save money" (P55).

While their choice to follow public health advice (or not) was in their control, it was at times difficult when navigating social aspects and obligations. Not being able to control the choices or behaviours of other people, including family members, was challenging: "I have a son who has an alcohol addiction and was couch surfing, out partying, very difficult to let him come back to live in the house" (P69). Indeed, many respondents worried that other people were "not taking COVID seriously" and, therefore, not following public health guidelines:

"The only difficult part is a lot of people do not respect the social distancing or follow the safety procedures" (P45).

"Other people don't practice social distancing and when you remind them, they get very upset." (P82).

Some respondents thought additional public health guidelines should be mandated to better control the actions of others: "I believe a curfew should be implemented for the ones drinking around still" (P6); "Wearing masks should be mandatory for all to wear in public to help stop the spread" (P69).

Regardless of domain (i.e., personal or public), people wanted information that was easily accessible, reliable, and transparent, "because [health advice] the best defense right now from COVID" (P6). Indeed, many respondents indicated they are "more mindful to seek medical and news 
about COVID" and appreciated transparency and sources being "truthful and honest about the virus and its effects":

"I found a vast difference of just reading on social media to see what health experts post or say. They have been consistent with updates and I'd rather hear from them other than non-professionals or other people in general. They have the best advice and know exactly what to do!" (P10).

Yet, other respondents were skeptical and critical of the quality and timing of information provided, explaining there was "conflicting [advice] at times" and "being too secretive regarding infection rates and slow to update information" (P63).

\section{"Public advice experts were too slow to react and did not take serious steps to protect the public. My family and I are doing more than what had been suggested" (P55).}

\section{Discussion}

During the endorsement of COVID-19 public health guidelines, we found respondents in this First Nations community in Alberta reported high levels of difficulty in their access to clothing, essential medical care, childcare, and food. In particular, participants with lower income reported higher difficulty in their access to essential medical care, clothing, and transportation. Further, people with two or more chronic conditions also reported higher difficulty in their ability to follow the "self-isolate" advice. The majority of respondents perceived guidelines for "proper handwashing" as most easy to follow; whereas "keeping a distance of $2 \mathrm{~m}$ from others" was perceived to be most difficult. As well, not being able to control the actions of others in not following the guidelines (i.e., social distancing) was challenging. In the context of public health communication about COVID-19, people reported the need for information that was easily accessible, reliable, and transparent.

Although our findings may not have directly referenced any "cultural" effects in their ability to follow COVID-19 guidelines, it is important to note that First Nations people throughout Canada (both on- and off-reserve, urban and rural) have experienced health disparities as a result of deeply rooted colonization and colonialism (Kim, 2019). Historically, starting with the Indian Act (1876) (Government of Canada, 1985), colonial laws continue to harm First Nations culture in favour of assimilation into Euro-Canada society. This oppression through policy choices and discourses of racial inferiority can be considered the root cause of inequity (Munari et al., 2021), as opposed to individual or community vulnerabilities. This systemic racism manifests in social exclusion of First Nations people, limiting or preventing political, social, and economic participationincluding access to and participation in health (Leyland et al., 2016). Furthermore, environmental dispossession and dietary erosion of traditional foods may result in food insecurity among First Nations people, contributing to increased rates of obesity, diabetes and other chronic diseases (Richmond et al., 2020). These inequities based on the social determinants of health not only contribute to the additional burden of health problems and food insecurity (Richmond et al., 2020), they also restrict First Nations people's ability to access quality health care and resources (Browne et al., 2011; Cameron et al., 2014), affecting not only those living in rural, remote reserves. Hence, knowing these pre-existing disparities we can infer that First Nations communities may experience COVID-19 guidelines and circumstances differently than the general population, including access to clean water for handwashing and adequate housing to facilitate physical distancing when necessary. Indeed, many of these issues around the basic social determinants of health could be seen in the respondents' perceptions and ability to respond to COVID-19.

The present study provides important insight on how COVID-19 may affect First Nations communities in Canada. Although responses are contextual, and therefore unique to this community, our design using simple survey techniques, along with content analysis of openended questions, is reproducible among other communities, Nations and other First Nations people (urban, offreserve). As this particular rural-reserve community had health support infrastructure and systems in place, it is reassuring to observe that the participants in this study were, to some degree, able to follow the recommended guidelines. Indeed, previous relationships with the research team heavily facilitated the readiness, planning and implementation of this study. Through dissemination activities, broader leadership, Confederation and Council meetings, other communities can learn through our findings, seek opportunities to ask and reflect on the experiences of their own people.

In all, these findings help contribute to the knowledge base on how COVID-19 has impacted the health of First Nations peoples, while at the same time, providing future direction to the field of public health on health communication and messaging. Although some respondents were critical of the COVID-19 advice, many responded to the openended questions with appreciation for the transparency and felt the information source was reliable. This is a reminder of the importance of tailored messaging to the community, including a respected source. For people to value, act and follow any public health guidelines, the advice must be perceived as meaningful and relevant (Barbera et al., 2001). For those who reported difficulty accessing health care, future research with additional contextual data is required 
to make recommendations to the community's systems and structures.

The major strength of this study is it is one of the few and first studies on First Nations communities and their perceptions of COVID-19 guidelines in Canada. Further, it is a very timely study as it captures the adequacy and level of health resources available to First Nations communities during the pandemic. However, the study is not without limitations. As mentioned, this particular community is one of the few exceptional communities in Alberta that already had a pre-existing robust health infrastructure. Thus, the findings may not be transferrable to other First Nations communities as the quality and quantity of health resources differ significantly among communities. Although we collaborated with the First Nations community on the survey development and recruitment, there are inherent limitations in self-report surveys and also with selection bias. Only one respondent per household was eligible to participate in the study, and so findings may not reflect the views of all family/household members. Also, our sample size was small and more than $80 \%$ female, which further limits the generalizability of our findings.

\section{Conclusion}

In addition to the ongoing challenges First Nations people face, following many aspects of the COVID-19 public health advice was difficult. People in this First Nations community also found some basic living requirements, like accessing food and essential medical care, more difficult with COVID19. These were sometimes magnified by other challenges, such as lower income and employment status. However, some respondents described following public health advice as manageable, such as handwashing, wearing masks, limiting excursions to protect their families, taking action to limit the spread of COVID-19 in their community. However, it will take continued collaborations and knowledge sharing with First Nations people to address larger issues of health inequities, like socio-economic and systemic racism factors, to address current and future public health emergencies. Unfortunately, for some the healthy choice is not the easiest choice.

\section{Contributions to knowledge}

What does this study add to existing knowledge?

- This study adds the perspective of living within the COVID-19 public health guidelines among First Nations people in Alberta.

- Many found aspects such as "keeping a distance of $2 \mathrm{~m}$ " challenging.

- Some found basic living requirements, such as accessing medical care and food, more difficult during this time.

What are the key implications for public health interventions, practice or policy?

- The key implications are the direction of future health communication and messaging among this community. Although some respondents were critical of the COVID19 advice, many voiced their appreciation for the transparency and felt the information source was reliable. This is proof of the importance of tailored messaging to the community, including a respected source, for people to follow guidelines.

\section{Appendix. Public health advice on COVID-19 and First Nations Survey}

\section{Public Health Advice on COVID-19 and First Nations}

\section{Survey}

Thank you for participating in our study by answering the following survey. Below is some information to help you answer this survey.

This confidential survey is about the appropriateness of public health advice for COVID-19 for First Nations and Metis people in Alberta.

There are no right or wrong answers to any of the questions.

Please read the questions carefully and answer each one according to what is true for you. Please answer each question to the best of your ability and please do not skip any questions. 


\section{Section A: About You}

We would like to know more about you.

A1. Are you:

$\square$ Male

$\square$ Female

$\square$ Transgender

$\square$ If these categories do not accurately reflect how you identify yourself, please use this space to write in your response:

$\square$ Prefer not to answer

A2. What is your age?

18-30

$31-44$

45-59

60 or older

A3. Which of the following best describes your ethnic background?

$\square$ First Nations Status from Treaty area in Alberta

$\square$ First Nations Status from another province

$\square$ First Nations non-status

Metis

$\square$ Other; please specify:

Prefer not to answer

A4. What is your marital status?

$\square$ Never married

$\square$ Married / common law

Divorced

Widowed

A5. What is the highest level of education you have completed?

$\square$ No formal schooling

Completed grade school (grades 1-9)

Completed high school

Completed College or University

Completed Graduate education (MS or PhD)

A6. What are the first 3 letters of the postal code where you are living/staying (for example, if your postal code was T7J 3W1, you would write T7J):

First 3 letters:

Not applicable

Prefer not to answer 
For the following questions, please think about the time right before COVID-19 as of March 1, 2020.

A8. What was your employment status immediately before to COVID-19?

$\square$ Homemaker

$\square$ Full-time employee

$\square$ Part-time employee

$\square$ Self employed

$\square$ Self-reliant or sufficient / living off the land

$\square$ Not in labor force-disabled

$\square$ Retired

$\square$ Unemployed

$\square$ Others; please specify:

A9. Which of the following categories best describes your total annual household income immediately before to COVID-19? (This should include income, before taxes, from all sources, wages, rent from properties, social security, disability benefits, help from relatives and so on...)

$\square$ Less than $\$ 20,999$

$\square \$ 21,000$ to 34,999

$\square \$ 35,000$ to $\$ 59,999$

$\square$ Greater than $\$ 60,000$

$\square$ Don't know

$\square$ Refuse to answer

A10. Which best describes your living arrangement immediately before to COVID$19 ?$

Own house or condominium

Renting, rooming house

Staying with family or friends / Couch surfing

$\square$ Shelter

Without a place to stay / homeless

Prefer not to answer

A11. How many people (including children, adults, grandparents, friends, etc.) were living with you or staying with you in the same place immediately before to COVID-19? (number)

\section{Section B: Your experiences}

"Public health is defined as the organized efforts of society to keep people healthy and prevent injury, illness and premature death. It is a combination of programs, services and policies that protect and promote the health of all Canadians. Throughout Canada, this work is led by the Public Health Agency of Canada. 
During COVID-19, the Public Health Agency of Canada has given specific advice to Canadians. You may have heard this advice from the Public Health Agency of Canada directly, or through local or regional organizations, like your local Health Services. We would like to know how appropriate this advice has been for you in your current situation.

\section{B1. Please tell us how easy or difficult it has been for you to follow the advice by public health experts.}

- Proper hand washing often with soap and water for at least 20 seconds, especially after using the washroom and when preparing food

- Use alcohol-based hand sanitizer if soap and water are not available

- Avoiding crowded places and non-essential gatherings

- Limiting contact with people at higher risk like older adults and those in poor health

- Keeping a distance of at least 2 arms-length (approximately 2 metres or a hockey stick) from others

- Self-isolate by staying at home and monitor yourself for symptoms

- Self-isolate by avoiding contact with others to help prevent transmission of the virus

- Follow travel advice including avoiding all non-essential travel

\begin{tabular}{|l|l|l|l|l|}
$\square$ Very easy & $\begin{array}{l}\square \text { Somewhat } \\
\text { easy }\end{array}$ & $\begin{array}{l}\square \text { Somewhat } \\
\text { difficult }\end{array}$ & $\square$ Very difficult & $\begin{array}{l}\square \text { Prefer not to } \\
\text { answer }\end{array}$ \\
\hline
\end{tabular}

Please tell us why it was easy or difficult for you to follow any of the advice from public health experts:

Have you considered or are you taking other advice or action suggested from other sources (such as social media like Twitter or Facebook, news sites) that may not been endorse by public health agencies?

\begin{tabular}{|l|l|l|l|}
\hline$\square$ Yes & $\square$ No & $\square$ Not Sure & $\square$ Prefer not to answer \\
\hline
\end{tabular}

How confident are you in the advice you're getting from public health experts.

\begin{tabular}{|l|l|l|l|l|}
\hline $\begin{array}{l}\square \text { Very } \\
\text { confident }\end{array}$ & $\begin{array}{l}\square \text { Somewhat } \\
\text { confident }\end{array}$ & $\begin{array}{l}\square \text { Somewhat } \\
\text { not confident }\end{array}$ & $\begin{array}{l}\square \text { Not } \\
\text { confident at all }\end{array}$ & $\begin{array}{l}\square \text { Prefer not to } \\
\text { answer }\end{array}$ \\
\hline
\end{tabular}

Because of public health advice about COVID-19, have you struggled to meet the following basic living requirements? (have to borrow money, miss bill payments to satisfy your basic living needs)

- Food

- Shelter

- Clothing

- Transportation

- Child care 
- Essential medical care (medications)

\begin{tabular}{|l|l|l|l|l|l|l|}
\hline $\begin{array}{l}\square \text { Not } \\
\text { at all }\end{array}$ & $\begin{array}{l}\square \\
\text { Sometimes }\end{array}$ & $\square$ Often & $\square$ Always & $\begin{array}{l}\square \text { Don't } \\
\text { know }\end{array}$ & $\begin{array}{l}\square \text { Not } \\
\text { applicable }\end{array}$ & $\begin{array}{l}\square \text { Prefer not } \\
\text { to answer }\end{array}$ \\
\hline
\end{tabular}

Because of public health advice about COVID-19, have you experienced any of the following?

- Increased use of alcohol or other substances

- Increased concerns for your safety or for the safety of people with whom you interact closely (for example, increased violence)

\begin{tabular}{|l|l|l|l|}
$\square$ Yes & $\square$ No & $\square$ Not Sure & $\square$ Prefer not to answer
\end{tabular}

Please tell us about how the advice from public health experts changed your experiences, if at all:

\section{Section C: Your Health}

We would like to know about your general health and the health of other people you interact with closely. Please answer these questions based on your current situation today.

Has a doctor ever told you that you have (had) any of the following conditions? (Check all that apply)

\begin{tabular}{|l|c|c|c|}
\hline & Yes & No & I don't know \\
\hline $\begin{array}{l}\text { Problems that make it hard for } \\
\text { you to breathe (example, } \\
\text { Asthma) }\end{array}$ & $\square$ & $\square$ & $\square$ \\
\hline Cancer & $\square$ & $\square$ & $\square$ \\
\hline $\begin{array}{l}\text { Heart problems (history of heart } \\
\text { attack) }\end{array}$ & $\square$ & $\square$ & $\square$ \\
\hline Stroke & $\square$ & $\square$ & $\square$ \\
\hline Diabetes & $\square$ & $\square$ & $\square$ \\
\hline $\begin{array}{l}\text { Problems with your immune } \\
\text { system (example, Crohn's) }\end{array}$ & $\square$ & $\square$ & $\square$ \\
\hline Kidney Disease & $\square$ & $\square$ & $\square$ \\
\hline Liver Disease & $\square$ & $\square$ & $\square$ \\
\hline Mental illness & $\square$ & $\square$ & $\square$ \\
\hline
\end{tabular}

Please tell us more about your emotional health. Over the last 2 weeks, how often have you been bothered by any of the following problems?

\begin{tabular}{|llll|} 
Not at all & $\begin{array}{l}\text { Several } \\
\text { days }\end{array}$ & $\begin{array}{l}\text { More than } \\
\text { half the } \\
\text { days }\end{array}$ & $\begin{array}{l}\text { Nearly } \\
\text { every } \\
\text { day }\end{array}$ \\
\hline
\end{tabular}




\section{Little interest or pleasure in doing} things

Feeling down, depressed, or hopeless

Feeling nervous, anxious, or on edge

Not being able to stop or control worrying

Did you feel Mental Health supports were available to you?

\begin{tabular}{|l|l|l|l|l|}
\hline$\square$ Yes & $\square$ No & $\begin{array}{l}\square \text { Don't } \\
\text { know }\end{array}$ & $\square$ Not applicable & $\begin{array}{l}\square \text { Prefer not to } \\
\text { answer }\end{array}$ \\
\hline
\end{tabular}

What unseen benefits or "silver linings", if any, have you experienced because of public health advice or COVID-19?

Is there anything else you'd like to tell us about your experiences with public health advice about COVID-19?

\section{Thank you for completing this survey.}

Supplementary Information The online version contains supplementary material available at https://doi.org/10.17269/ s41997-021-00579-4.

Acknowledgements Thank you to First Nations leadership and staff, for initiating this project and partnering in its design, planning and implementation to support the Nation's response to the COVID-19 pandemic.

Author contributions All authors contributed to the study conception and design. Material preparation and data collection were performed by Allison Soprovich, Lisa Wozniak, Cerina Lee, Vishal Sharma, Salim Samanani, and Dean Eurich. Data analysis was performed by AS, LW, VS and DE. The first draft of the manuscript was written by AS, CL and LW. All authors commented on previous versions of the manuscript. All authors read and approved the final manuscript.

Funding N/A.

Availability of data and material All data and materials are available by written request to the corresponding author.
Code availability Code is available by written request to the corresponding author.

\section{Declarations}

Ethics approval All procedures performed in studies involving human participants were in accordance with the ethical standards of the institutional and/or national research committee (Health Research Ethics Board at the University of Alberta (reference \# Pro00099663)) and with the 1964 Helsinki declaration and its later amendments or comparable ethical standards.

Consent to participate Informed consent was obtained from all individual participants included in this study.

Consent for publication All authors consent to the publication of this manuscript.

Conflict of interest The authors declare they have no conflict of interest. 


\section{References}

Alberta Health Services. (2020). Information for Albertans: Novel coronavirus (COVID-19). Available from: https://www. albertahealthservices.ca/topics/Page16997.aspx\#social.

Ali, S., Asaria, M., \& Stranges, S. (2020). COVID-19 and inequality: Are we all in this together? Canadian Journal of Public Health, 111(3), 415-416.

Arriagada P. (2016). Aboriginal peoples: Fact sheet for Alberta.

Assembly of First Nations. (2011). Fact sheet: Quality of life of First Nations.

Barbera, J., Macintyre, A., Gostin, L., Inglesby, T., O'Toole, T., DeAtley, C., et al. (2001). Large-scale quarantine following biological terrorism in the United States: Scientific examination, logistic and legal limits, and possible consequences. JAMA, 286(21), 2711-2717.

Browne, A. J., Smye, V. L., Rodney, P., Tang, S. Y., Mussell, B., \& O'Neil, J. (2011). Access to primary care from the perspective of Aboriginal patients at an urban emergency department. Qualitative Health Research, 21(3), 333-348.

Cameron, B. L., Carmargo Plazas Mdel, P., Salas, A. S., Bourque Bearskin, R. L., \& Hungler, K. (2014). Understanding inequalities in access to health care services for aboriginal people: A call for nursing action. ANS. Advances in Nursing Science, 37(3), E1-E16.

First Nations Information Governance Centre. (2018). National report of the First Nations Regional Health Survey Phase 3. Ottawa, ON.

First Nations Information Governance Centre. (2021). The First Nations principles of OCAP. Akwesasne, ON. Available from: https://fnigc.ca/ocap-training/\#: :text=The\%20First\%20Nations\% 20principles $\% 20$ of $\% 20$ ownership $\% 2 \mathrm{C} \% 20$ con trol $\% 2 \mathrm{C} \%$ 20 access $\% 2 \mathrm{C} \% 20$ and,this\%20information $\% 20$ can\%20be\%20used.

Government of Alberta. (2020). Chief Medical Officer of Health order: 2020 COVID-19 response. Available from: https://open.alberta. $\mathrm{ca} /$ dataset? $\mathrm{q}=\&$ sort $=$ metadata_created + desc \&pubtype $=$ Orders + and+Directives\&tags $=$ COVID -19 .

Government of Canada. (1985). Indian Act. Available from: https:// laws-lois.justice.gc.ca/eng/acts/i-5/.
Government of Canada. (2020). Epidemiological summary of COVID19 cases in First Nations communities. Available from: https:// www.sac-isc.gc.ca/eng/1589895506010/1589895527965.

Hsieh, H. F., \& Shannon, S. E. (2005). Three approaches to qualitative content analysis. Qualitative Health Research, 15(9), 1277-1288.

Kim, P. J. (2019). Social Determinants of Health Inequities in Indigenous Canadians Through a Life Course Approach to Colonialism and the Residential School System. Health Equity, 3(1), 378-381.

Kitching, G. T., Firestone, M., Schei, B., Wolfe, S., Bourgeois, C., O'Campo, P., et al. (2020). Unmet health needs and discrimination by healthcare providers among an Indigenous population in Toronto, Canada. Canadian Journal of Public Health, 111(1), 40-49.

Leyland A, Smylie, J., Cole, M., Kitty, D., Crowshoe, L., McKinney, M., Green, M., Funnell, S., Brascoupe, S., Dallaire, J., \& Safarov, A. (2016). Health and health care implications of systemic racism on Indigenous Peoples in Canada.

Munari, S. C., Wilson, A. N., Blow, N. J., Homer, C. S. E., \& Ward, J. E. (2021). Rethinking the use of 'vulnerable.' Australian and New Zealand Journal of Public Health, 45(3), 197-199.

National Collaborating Centre for Aboriginal Health. (2013). An overview of Aboriginal health in Canada.

Qualtrics. (2005). Qualtrics XM: 2019. Provo, Utah, USA.

Richmond, C., Steckley, M., Neufeld, H., Kerr, R. B., Wilson, K., \& Dokis, B. (2020). First nations food environments: Exploring the role of place, income, and social connection. Current Developments in Nutrition, 4(8), nzaa108.

Scientific Software Development GmbH. (n.d.) ATLAS.ti: Qualitative Data Analysis Version 8.

StataCorp LLC. (2017). Stata Statistical Software: Release 15. College Station, Texas, USA.

Statistics Canada. (2015). Aboriginal statistics at a glance: 2nd edition.

Publisher's Note Springer Nature remains neutral with regard to jurisdictional claims in published maps and institutional affiliations.

\title{
Authors and Affiliations
}

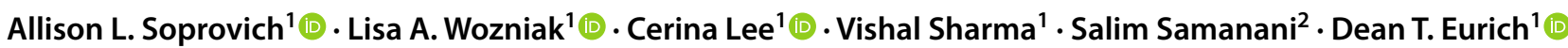 \\ Dean T. Eurich \\ 2 OKAKI Health Intelligence Inc., Calgary, AB, Canada
}

deurich@ualberta.ca

1 School of Public Health, University of Alberta, Edmonton, $\mathrm{AB}$, Canada 